\title{
The Limits of Foreign Aid Diplomacy: How Bureaucratic Design Shapes Aid Distribution
}

\author{
Vincent AREL-Bundock \\ Université de Montréal \\ James AtKinson \\ University of Michigan \\ AND \\ Rachel Augustine Potter \\ University of Virginia
}

\begin{abstract}
How does the institutional design of a state's bureaucracy affect foreign policy? We argue that institutions can moderate bureaucrats' incentives to act in accordance with an Executive's diplomatic preferences. Where the Executive can influence budgets or career paths, bureaucrats face incentives to adopt her diplomatic goals as their own. Where agencies are shielded from Executive influence, bureaucrats are free to act independently in a bid to enhance their autonomy and their reputation for competence. To test these expectations, we develop a new measure of bureaucratic independence for the 15 aid-giving agencies in the US government. We analyze how independence affects foreign aid allocation patterns over the 1999-2010 period. We find that in "dependent" agencies, foreign aid flows track the diplomatic objectives of the president. In "independent" agencies, aid flows appear less responsive to presidential priorities and more responsive to indicators of need in the recipient country. Our results highlight limits on the diplomatic use of foreign aid and emphasize the importance of domestic institutional design. Our findings yield insight into a broad range of policy domains-including international finance, immigration, and the application of economic sanctions-where multiple government agencies are in charge of implementing foreign policy.
\end{abstract}

Presidents and prime ministers figure prominently in the formulation of their nation's foreign policy. Implementing an Executive's decisions, however, requires the cooperation of a much broader set of actors. For instance, the military operations and subsequent reconstruction efforts that George W. Bush initiated in Iraq drew contributions from a diverse array of government agencies, including five Cabinet-level Departments and an independent agency. ${ }^{2}$ The same pattern arises in many other issue areas, such as economic sanctions and immigration policy, where a fragmented group of bureaucrats - who may or may not share the Executive's preferences-is in charge of implementation.

In this article, we study patterns of foreign aid-giving to assess how the institutional design of bureaucratic agencies affects the realization of Executive preferences. Like

Vincent Arel-Bundock is an assistant professor of political science at the Université de Montréal.

James Atkinson is a $\mathrm{PhD}$ candidate in political science at the University of Michigan.

Rachel Augustine Potter is an assistant professor of political science at the University of Virginia.

${ }^{1}$ We use the term "Executive" to refer to a country's primary leader. For reasons of gender parity, we use feminine pronouns to refer to the Executive throughout this paper.

${ }^{2}$ The five Cabinet-level agencies are the Department of Commerce, Department of Defense, Department of Energy, Department of State, and Department of Treasury. The independent agency is the US Agency for International Development. many scholars before us, ${ }^{3}$ we focus on the use of foreign aid as a tool of diplomacy that advances a donor country's economic and security self-interest. This "diplomatic" view of aid-giving has received extensive empirical support, but we argue that it rests on an incomplete theoretical foundation.

Specifically, we take issue with the implicit-and erroneous-assumption that aid dollars are discretionary funds that the Executive can freely deploy to target recipients abroad. ${ }^{4}$ This premise is unrealistic. The executive is not typically responsible for the implementation of aid programs. Instead, she relies on agencies - such as the United Kingdom's Department for International Development (DFID) - to disburse these funds. Furthermore, the Executive who wants to guide foreign aid, or official development assistance (ODA), allocation usually contends with more than one aid-giving agency. Sweden, for instance, used at least six different government agencies to send ODA abroad in the last ten years; Germany used no fewer than 17. In any given year, 15 different agencies within the American government may disburse foreign aid (Tierney, Nielson, Hawkins, Timmons Roberts,

\footnotetext{
${ }^{3}$ See, for example, Alesina and Dollar (2000); Berthelémy and Tichit (2004); Boone (1996); Bueno de Mesquita and Smith (2007); Bueno de Mesquita and Smith (2009); Heinrich (2013); Kuziemko and Werker (2006); Lancaster (2007); Maizels and Nissanke (1984); McKinlay and Little (1977); Meernik, Krueger, and Poe (1998); Schraeder, Hook, and Taylor (1998).

${ }^{4}$ Instead of developing leader-centric theories of aid allocation, much of the empirical literature on ODA blackboxes the government. From that perspective, our argument offers a richer account of the domestic processes that direct aid-giving.
} 
Findley, Powers, Parks, Wilson, and Hicks 2011). This oversight matters, as it leads scholars to mischaracterize the Executive's ability to deploy ODA as a tool of diplomacy. It may also camouflage important patterns of aidgiving at the subnational level and obscure the crucial role of domestic institutions in foreign policy.

We examine how, in the American case, the institutional design of the aid-giving bureaucracy affects the Executive's ability to assert control over ODA allocation. We show that American agencies that distribute ODA vary broadly in their degree of independence from the Executive. Their different levels of susceptibility to institutionalized political pressure, in turn, translate into markedly different aid-giving patterns. Where bureaucrats are "dependent" on the Executive, aid flows appear tightly linked to the diplomatic objectives of the president, such as strengthening military alliances and promoting bilateral trade. Where bureaucrats enjoy an "independent" position, however, ODA flows appear more responsive to recipient need.

Our results highlight the role of domestic institutional design as a limit on the diplomatic use of foreign aid. Our findings also have implications across a broad range of foreign policy domains where multiple government agencies control implementation. In terms of transgovernmental politics, for instance, independent agencies that can resist executive pressure may take a stance on foreign policy issues that diverges from the preferences of the Executive. This may result in foreign governments receiving mixed messages when they interact with independent bureaucratic agencies. And, in some cases, it can lead to a loss of foreign policy coherence.

In the next section, we situate our work in the broader International Relations literature. We point out that most prior research on aid-giving focuses on political institutions on the recipient side, it ignores the problems that executives face when they try to assert control over their own bureaucracies. Our paper challenges these approaches by demonstrating how institutional characteristics on the donor side affect who gives foreign aid to whom and why. We then draw on work from the field of American politics to define the concept of agency independence, and introduce a novel measure of independence for US aid-giving agencies. We conclude with the results of a regression analysis that supports our claim for a moderating effect of agency independence on the relationship between, on the one hand, diplomatic and development motives and, on the other, ODA flows.

\section{Foreign Aid as a Tool of Diplomacy}

Research on the determinants of foreign aid-giving suggests that donors focus on diplomatic rather than development considerations when they choose where to disburse aid. ${ }^{5}$ McKinlay and Little (1977) propose one of the first modern empirical tests of this proposition. They find little evidence that levels of foreign aid correlate with the social and economic needs of recipient countries. In contrast, they find strong support for the idea that the diplomatic interests - such as economic and security concernsof donor countries influence aid disbursal decisions. This finding is robust to a number of proxy measures for

${ }^{5}$ We follow Lancaster (2007:ix) by referring to goals associated with "advancing the national security and economic interests of the donor country" as "diplomacy," and by referring to efforts to "help better the human condition in countries receiving the aid" as "development." security and economic incentives, including bilateral trade (Meernik et al. 1998; Schraeder et al. 1998; Berthelémy and Tichit 2004; Bueno de Mesquita and Smith 2007, 2009), foreign direct investment (Alesina and Dollar 2000; Berthelémy and Tichit 2004), security alliances (Meernik et al. 1998; Schraeder et al. 1998; Bueno de Mesquita and Smith 2007, 2009), US troops stationed in the recipient country (Meernik et al. 1998), UN votes and Security Council seats (Alesina and Dollar 2000; Kuziemko and Werker 2006), and geographic distance (Neumayer 2005; Bueno de Mesquita and Smith 2007, 2009; Fink and Redaelli 2011; Raschky and Schwindt 2012; Dietrich 2013; Heinrich 2013). Moreover, diplomatic considerations prove influential even when we might expect development concerns to trump them. For instance, Fink and Redaelli (2011) and Raschky and Schwindt (2012) find that economic and security motives guide postdisaster relief aid distribution.

Numerous works articulate the theoretical underpinnings for these findings (for example, Maizels and Nissanke 1984; Boone 1996; Schraeder et al. 1998; Alesina and Dollar 2000; Berthelémy 2006; Bueno de Mesquita and Smith 2007; Bearce and Tirone 2010; Heinrich 2013). Most directly, Bueno de Mesquita and Smith (2009) explain how government leaders' desire to stay in office leads them to offer foreign aid in exchange for policy concessions by recipients. This argument rests on the implicit assumption, shared by much of this literature, that flows of development assistance move unproblematically from the Executive in the donor country to the recipient country.

Of course, some may dismiss this assumption as an innocuous empirical convenience since, until recently, aid data remained unavailable at the subnational level. Yet, we argue that this assumption can lead to a skewed interpretation of Executive authority with respect to ODA. Indeed, scholars who study aggregated aid flows may overstate the Executive's ability to direct ODA from independent agencies, but understate the extent of her control over dependent agencies. In that sense, leadercentric theories and "black box" empirical approaches risk masking a great deal of heterogeneity in ODA flows, and may fail to capture the micro-level mechanisms that direct aid flows.

Our approach complements recent work that shows a more nuanced understanding of disaggregated foreign aid flows. For example, we now know that donors choose strategically between various forms of aid, such as grants, food, or emergency relief (Fariss 2010; Raschky and Schwindt 2012). Donors also provide aid through multiple channels, including bilateral, multilateral, or non-governmental organizations (Maizels and Nissanke 1984; Winters 2010; Dietrich 2013). Furthermore, domestic political institutions on the recipient side can condition how much aid is received, and what effects it has on local populations (Svensson 1999; Burnside and Dollar 2000; Bueno de Mesquita and Smith 2009; Lebovic and Voeten 2009; Dietrich 2013).

We make a novel contribution to this scholarly discussion by drawing attention to a crucial, but oft-ignored, determinant of aid allocation patterns: the structure of the aid-giving bureaucracy on the donor country side. ${ }^{6}$

\footnotetext{
${ }^{6}$ It is important to note the distinction between our approach, which emphasizes the choice of recipients, and the important strand of literature which links domestic political institutions to aid-giving levels. See Noel and Therien (1995) and Therien and Noel (2000).
} 
Specifically, we point to how the institutional design of aidgiving agencies affects who receives aid and, critically, how much say the Executive has in such decisions. In the next section, we explore a key agency design feature-whether the agency is "independent" from the Executive-in the context of American aid allocation decisions.

\section{Agency Independence and Foreign Policy Preferences}

Our core argument is that an agency's structural design can moderate bureaucrats' incentives to allocate aid dollars in accordance with Executive preferences. In the United States, some "dependent" agencies are institutionally tied to the president, and this allows her to punish or reward the decisions of bureaucrats who work within those agencies. Other agencies, in contrast, enjoy structural insulation from presidential influence; bureaucrats who work in these "independent" agencies often feel less pressure to support the president's foreign policy agenda.

In this section, we leverage the concept of agency independence to develop expectations about aid-disbursement patterns. First, we draw on the bureaucratic independence literature to identify a set of formal institutional features that can insulate agencies from influence by the Executive. Then, we argue that the Executive's preferences over foreign policy lead her to favor the allocation of ODA to countries that help advance her military and economic agenda. Finally, we point out that a different set of concerns-including public service, budget maximization, and career advancement-motivates bureaucrats and that those goals should have an indirect influence on the choice of aid recipients. Where the Executive can influence budgets or career paths, bureaucrats face incentives to adopt the president's diplomatic goals as their own. Where agencies are protected from Executive influence, the public service orientation of bureaucrats may lead them to direct aid where it is most needed.

\section{Agency Independence}

"Agency independence" is a core concept in the study of the American bureaucracy. ${ }^{7}$ Scholars have proposed numerous definitions, but the unifying theme is a focus on the extent of influence that the president can wield over bureaucrats (for example, Devins and Lewis 2008). As Justice Scalia puts it, "independent agencies are sheltered not from politics but from the President" (Barkow 2010:26). ${ }^{8}$

\footnotetext{
7 The idea of creating institutional safeguards to isolate bureaucrats from political influence is neither new nor unique to the study of American politics, however. For instance, in the field of political economy, scholars argue that delegating monetary authority to an independent central bank can reduce inflation and is associated with a variety of desirable macroeconomic outcomes. See Alesina and Summers (1993); Barro and Gordon (1983); Cukierman (1992); De Long and Summers (1992); Lohmann (1992); Rogoff (1985). In this context, "independence" is understood to mean "how far the bank could stray from the current government's desires before the latter would prefer to pay the costs of altering the bank law or of seizing the monetary reins itself" (Franzese 1999:682).

${ }^{8}$ Whether institutional safeguards translate into effective independence in practice remains an open (empirical) question. On the one hand, scholars find evidence that design can be effective at buffering the president (Hammond and Knott 1996; Lewis 2003; Wood and Bohte 2004; Devins and Lewis 2008; Selin forthcoming). On the other, Bressman and Thompson (2010:601) note that "even if an independent agency is not under the thumb of the President, it might still feel the hand of the President."
}

In practice, the degree of independence that an agency enjoys depends on institutional factors, such as its organizational "proximity" to the president. For example, the Office of Science and Technology, which is part of the Executive Office of the President, is often considered less independent than the Department of Labor, an agency within the president's Cabinet. Both agencies, however, are closer to the presidential orbit than the US Trade and Development Agency (TDA), which is separate from the Executive branch and whose leaders do not report directly to the president. This distinction is reflected in Table 1, where we list all 15 aid-giving agencies along with a basic classification as "Executive" or "Independent."

While this simple classification scheme helps introduce the idea of independence, the concept is decidedly more nuanced. In addition to basic proximity to the president, other institutional safeguards can serve to shield an agency from the Executive. Because appointments and firings are a primary source of presidential power (Selin forthcoming), personnel protections are commonly used to mitigate the Executive's influence. An expertise requirement, for example, minimizes the risk that the president will appoint an incompetent but politically connected agency head. Likewise, fixed terms in office may reduce the likelihood of politically motivated firings. Such safeguards can take a variety of forms, but they are designed to bolster the independence of an agency so that it is free to pursue its organizational goals.

Design choices are made at the time of an agency's creation (Lewis 2003:21-38), and legislators clearly anticipate the effects of these choices on agency decision making. For example, the Millennium Challenge Corporation (MCC) was established as an independent agency in large part because of concerns that its development focus would be compromised if it were housed within an executive branch agency (Lancaster 2007:106-7). According to the Congressional Research Service, a "reason for not placing the [Millennium Challenge Account (MCA) $]^{9}$ within the State Department may have been a concern that it would be located too close to the center of the US foreign policy apparatus that would limit the program's immunity from strategic and political influences" (Nowels 2003:20). Echoing this sentiment, then-Senator Joseph Biden argued against placing MCA under the control of the State Department due, in part, to his opposition to recent decisions by Republicans to move other independent agencies into State, thus "making the [S] ecretary (of State) the captain of foreign policy" (Sorrells 2003). By giving the MCA to a newly created independent agency, legislators understood that presidents would have less influence on spending decisions.

Over time, agency design choices are maintained through a variety of political oversight mechanisms, such as investigations, personnel decisions, and budget allocations. ${ }^{10}$ While Congress and the president jointly perform

\footnotetext{
9 The MCA is the aid program that came to be administered by the Millennium Challenge Corporation (MCC).

${ }^{10}$ For instance, an agency's budget can limit that agency's level of independence by including stipulations on how agency funds may or may not be spent. Conversely, the absence of such stipulations may enhance an agency's autonomy. Generally, agency budgets are the result of negotiations between the president and Congress as part of the annual appropriations process; to have an agency budget, both chambers of Congress must pass an appropriations bill, which the president must sign. For most dependent agencies, the president has first and last mover advantage, since she vets agency budgets at the proposal stage and signs (or vetoes) appropriations bills at the final stage.
} 
TABLE 1. Foreign Aid Agencies in the United States

\begin{tabular}{llc}
\hline Agency name & Abbr. & Binary independence classification \\
\hline Department of Agriculture & USDA & Executive \\
Department of Defense & DOD & Executive \\
Department of Energy & DOE & Executive \\
Department of Health and Human Services & HHS & Executive \\
Department of the Interior & DOI & Executive \\
Department of Labor & DOL & Executive \\
Department of State & STATE & Executive \\
Department of the Treasury & TREAS & Executive \\
Export-Import Bank of the United States & EXIM & Independent \\
Millennium Challenge Corporation & MCC & Independent \\
Office of Science and Technology & OST & Executive \\
US Agency for International Development* & AID & Independent \\
US African Development Foundation & ADF & Independent \\
US Institute of Peace & USIP & TDA \\
US Trade and Development Agency & Independent & Independent \\
\hline
\end{tabular}

(Note. *USAID constitutes a significant portion of US ODA (66\% in 2010). However, the amounts given by the other agencies are still very large and substantively important, see Figures S1 and S2. For example, the MCC, which committed five percent of the US foreign aid budget in 2010, gave more than the ODA disbursements from each of 15 OECD countries: South Korea, Turkey, Ireland, Portugal, Greece, Luxembourg, Poland, New Zealand, Czech Republic, Israel, Hungary, Slovakia, Slovenia, Iceland, and Estonia (Provost 2011).)

oversight of agencies, in the context of our argument about ODA, we focus on the influence of the president for two reasons.

First, when it comes to questions of foreign policy, the president remains paramount. As Wildavsky (1966:7) famously asserted, "in the realm of foreign policy, there has not been a single major issue on which presidents, when they were serious and determined, have failed." Canes-Wrone, Howell, and Lewis (2008:5) build on this "two presidencies" thesis, arguing that presidents have informational and first-mover advantages over Congress, and that "distinctive electoral incentives across the two branches of government encourage greater presidential influence over foreign than domestic policy." The authors conclude that, between 1969 and 2000, the president's supremacy in foreign policy led Congress to delegate much of its decision-making power to the Executive. So when agencies seek out political leadership on foreign policy issues, it is natural that they turn to the White House rather than to Capitol Hill.

Second, congressional preferences over foreign policy and foreign aid are less predictable and coherent than those of the president. Even if an aid-giving agency wanted to be responsive to Congress, it is not clear ex-ante which congressional actors would matter at that time and for that issue. In the 111th Congress (2009-2010), for example, 18 committees and 44 subcommittees held hearings related to international affairs or foreign aid. ${ }^{11}$ Furthermore, even if the set of relevant actors was clear, an agency may still not be able to anticipate the preferences of those actors, since there is no clear partisan divide with respect to ODA allocation. Rather, Milner and Tingley (2010) find that congressional support for aid varies based on the type of aid in question and on the characteristics of a legislator's district. And even

\footnotetext{
${ }^{11}$ Committee data from the Policy Agendas Project, http://www.policyagendas.org/. To determine the number of unique committees and subcommittees, we subsetted the data to the Congress in question and identified hearings on major topic "19" (International Affairs and Foreign Aid). While this includes some hearings that are not specifically about ODA, international affairs hearings may touch on country-specific issues that bear indirectly on ODA decisions.
}

individual legislators can send mixed messages about their preferences over foreign aid allocation. ${ }^{12}$ Thus, to the extent that agency bureaucrats attempt to match ODA flows to the preferences of political actors, we expect to see a bias toward the president, a unitary actor with a more coherent set of preferences.

\section{Executive Preferences}

Foreign policy is a central component of any president's agenda (Wildavsky 1966; Moe and Howell 1999; Canes-Wrone 2005; Canes-Wrone et al. 2008), and foreign aid presents an opportunity to further her diplomatic goals. As such, it is reasonable to expect that the president will prefer to distribute foreign aid in ways that advance traditional notions of the national interest, particularly military and economic security (Krasner 1978; Hibbs 2000; Lewis-Beck and Stegmaier 2000).

The electoral connection closely ties the president to the national interest. While perhaps not quite "singleminded" in the Mayhewian sense, reelection concerns-or party and legacy concerns for term-limited presidentsfigure prominently in the literature on the American presidency (Neustadt 1962; Tulis 1987). Currying favor with voters means tending myopically to the nation's economic and military interests. While American citizens are notoriously detached from foreign policy (Delli Carpini and Keeter 1993; Holsti 2004), when they do engage, it is nearly always in matters of pressing security (Powlick and Katz 1998) or economic (Mansfield, Milner, and Rosendorff 2002) importance. As a result, questions of foreign aid-like most nuts and bolts issues of foreign policytend to operate well beneath the public's radar (Page

\footnotetext{
${ }^{12}$ For instance, while arguing against cuts to the budget, Senator Patrick Leahy (D-VT) lauds both diplomatic and development priorities by stating that foreign aid "promotes US exports, supports democratic elections, combats poverty, and helps build alliances to counter terrorism, thwart drug trafficking, protect the environment, and stop cross-border crime" (Leahy 2011).
} 
and Shapiro 1983; Ostrom and Simon 1985). The implication is that presidents prefer to allocate aid to those countries that bolster military and economic interests. ${ }^{13}$

\section{Bureaucrats' Incentives}

Students of bureaucratic politics and public administration identify a host of motivations for bureaucrats (see Golden 2000). We explore how three central motives from this literature - agency reputation, budget maximization, and career advancement-indirectly translate into preferences over foreign aid disbursement. As we explain below, agency structure can enable the Executive to manipulate bureaucrats' incentives in order to target aid in ways that support the president's diplomatic agenda.

To begin, a sense of professionalism or duty to public service often motivates bureaucrats (Derthick and Quirk 1985; Wilson 1989; Brehm and Gates 1993; Dilulio 1994; Golden 2000). While this may initially seem altruistic, it can also serve bureaucrats' self-interest. By enhancing their reputation for competence and efficacy, bureaucrats can build autonomy for their organization (Carpenter 2001:3-11). Carpenter (2010:56) explains that "pay, budget maximization, and material goods will be valued less highly than status and esteem" and that reputation serves as a proximate goal to many different ends. In the context of ODA, the surest way for bureaucrats to signal professionalism, impartiality, and public spiritedness is to select recipients based on "objective" need-based indicators. ${ }^{14}$ This suggests that bureaucrats' efforts to secure autonomy should lead them to prefer giving to countries where development needs are greatest. Where the Executive cannot frustrate these efforts (i.e., in independent agencies), the link between recipient need and ODA receipts should be stronger.

Niskanen (1971) points to another motive when he argues that bureaucrats seek to maximize agency budgets. This theory leads us to expect that dependent agencies will exhibit a bias toward presidential priorities. To see why, consider that most dependent agencies submit draft budget proposals to the president's Office of Management and Budget (OMB). OMB acts as a gatekeeperreviewing each agency's proposal alongside those of other agencies, and making cuts to programs in order to adhere to a top line figure-before submitting the entire budget to Congress for approval. This budgetary oversight may enable the Executive to influence policymaking at the agency level. Independent agencies, in contrast, do not engage in the same negotiations with OMB. Instead, they submit their own budget request directly to Congress or they may have their own funding streams, which are not subject to the annual appropriations process. For instance, the U.S. Institute of Peace-an independent aid-giving agency-enjoys a "budget bypass," meaning that it is not required to have its budget approved by $\mathrm{OMB}$ prior to submitting it to Congress. This suggests

\footnotetext{
${ }^{13}$ We do not argue that the Executive only cares about diplomatic goals. Indeed, Heinrich (2013) identifies conditions under which the Executive may prioritize development goals. Nevertheless, we expect that an electorate that primarily focuses on economic and security concerns will lead the Executive to emphasize diplomatic goals when distributing foreign aid.

${ }^{14}$ In recent years, several critics have decried the lack of transparent and systematic measures of aid effectiveness (Lawson 2013; International Aid Transparency Initiative 2014). In the absence of agreed-upon competence metrics, the degree to which an aid-giving agency is attuned to recipient need often serves as a proxy for bureaucrats' type for the public, the media, and other stakeholders.
}

that independent agencies should be less beholden to presidential priorities, even if they are budget-focused.

Finally, some scholars argue that agency bureaucrats seek to enhance their own career prospects (Kaufman 1960; Golden 2000:20-25; Gailmard and Patty 2007). In dependent agencies, many of the leaders serve "at the pleasure of the president." These political appointees usually share the same party affiliation as the president, and tend to be selected for their fealty to her policy program. As a result, career-focused bureaucrats are likely to steer policy toward presidential priorities, in an attempt to curry favor with the Executive. Doing so can help them secure future promotions and enhance their standing in the party. Independent agencies, on the other hand, have fewer presidential appointees. They also tend to have staggered board or commission leadership structures. This weakens the ties between the current presidential administration and the career path of individual bureaucrats.

Taken together, existing theories of bureaucratic motivation suggest that the institutional design of an agency may serve to temper or exacerbate incentives to succumb to political pressure by the Executive. Efforts to gain autonomy reinforce bureaucrats' public service orientation and encourage need-based giving. In independent agencies, this tendency is unimpinged. In dependent agencies, however, the personal and organizational payoffs for diplomacy-enhancing ODA may be higher, because the president can bestow greater rewards and impose dearer costs. We therefore expect dependent agencies to disburse foreign aid in ways that are consistent with the administration's broader diplomatic goals of military and economic security. In contrast, we expect the tendency of aid bureaucrats to allocate funds based on development need to be strengthened in independent agencies.

To be clear, we do not expect that dependent agencies will only allocate funds to meet diplomatic objectives, nor do we suggest that independent agencies will only focus on recipients' development needs. Agencies serve a variety of functions, only some of which can be characterized as development-related, and they do so using a portfolio of policy instruments. ${ }^{15}$ Rather, we propose that when it comes to selecting foreign aid recipients, agency independence affects the relative weight that bureaucrats place on diplomatic and development concerns.

\section{Measuring Agency Independence}

To test these propositions, we build an index measure of independence for 89 US government agencies, including the 15 that disburse foreign aid. This index leverages data from the Sourcebook of United States Executive Agencies (Lewis and Selin 2012), and aggregates information on nine institutional characteristics, which help insulate agencies from elected political leaders' influence. For example, we

\footnotetext{
${ }^{15}$ For example, the budget of the Department of State-an agency that is in the president's Cabinet and which we categorize as highly dependentincludes a variety of activities that are oriented toward presidential priorities like "investments in the stability, security, and development of Afghanistan and Pakistan." However, the budget also includes activities that appear more development-oriented, such as a "comprehensive and integrated global health strategy toward achieving an AIDS-free generation and ending preventable child and maternal deaths" (Department of State 2014). We acknowledge that the patterns we propose here are not absolutes and that public relations and legal requirements may cause deviations from these broader trends.
} 
TABLE 2. Agency Independence: 1st Principal Component Loadings

\begin{tabular}{|c|c|c|c|}
\hline Variable & Expectation & Loadings & Description \\
\hline Fixed terms & + & 0.467 & 1 if members, commissioners, or agency heads are appointed for fixed terms. 0 otherwise. \\
\hline Independent & + & 0.417 & $\begin{array}{l}1 \text { if the agency is outside the Executive Office of the President or is not an executive department. } \\
0 \text { otherwise. }\end{array}$ \\
\hline For cause & + & 0.348 & 1 if restrictions are in place for dismissal of the agency head. 0 otherwise. \\
\hline Expertise & + & 0.335 & 1 if expertise or experience requirement on nominations at the agency. 0 otherwise. \\
\hline Commission & + & 0.33 & $\begin{array}{l}1 \text { if agency is governed by a board or commission whose members are protected from removal. } \\
0 \text { otherwise. }\end{array}$ \\
\hline Serve President & - & -0.072 & 1 if officials serve at the pleasure of the President. 0 otherwise. \\
\hline PA & - & -0.074 & Log number of presidential appointees. \\
\hline PAS & - & -0.264 & Log number of presidential appointees with Senate confirmation. \\
\hline Schedule C & - & -0.431 & Log number of Schedule C excepted appointments. \\
\hline
\end{tabular}

(Note. Variable descriptions adapted from Lewis and Selin (2012).)

consider whether or not an agency is part of the Executive branch, if the agency head can be removed without cause or between regular/fixed terms in office, and the number of positions that are subject to presidential appointment (see Table 2 for a full list).

Our objective was to produce an index that effectively summarizes those institutional features, while also reducing the dimensionality of the problem at hand. We also want to avoid procedures that assign a priori weights to each of the variables - such as simple averaging-because we cannot know exactly how each of them contributes to independence. Principal components analysis (PCA) is a natural way to achieve these goals. ${ }^{16}$ This technique allows us to derive "optimal" weights from the data, and it produces scores which can be used to summarize the variance found in the institutional characteristics data set. ${ }^{17}$ We thus normalize the nine variables to have mean zero and a standard deviation of one, and use them to estimate a PCA model. We rescale the first principal component to ensure that all aid-giving agencies score between zero (dependent) and one (independent), and use the resulting variable as our measure of agency independence in subsequent regression analyses.

Table 2 allows us to assess the validity of our measurement model; it states our expectations and reports the estimated loadings/weights for each of the variables that we include in the PCA model. A plus sign in the second column indicates that the variable should be positively related to an agency's degree of independence. For example, fixed terms in office for the agency head should increase her degree of independence,

\footnotetext{
${ }^{16}$ PCA enables us to summarize the variation in the nine institutional features, reducing it to a low-dimensional index that can effectively act as a measure of agency independence. An alternative approach is to model agency independence as a latent concept, as Selin (forthcoming) does also using the Sourcebook of United States Executive Agencies data. Her approach further differs from ours in that she measures agency independence on a two-dimensional space, whereas we consider a single dimension. In practice, PCA and factor analysis are often used interchangeably. In Table S11 of the appendix, we show that replacing our measure with Selin's (institutional) measure of agency independence does not substantively affect our conclusions.

17 While we believe that the "agnostic" PCA approach is ultimately appropriate in the context of this paper, this approach forces us to ignore relevant prior information about the relative importance of individual components. In particular, the question of whether an agency is part of the Executive Office of the President should be a major consideration in our assessment (this dummy variable is often used on its own to measure agency independence in the bureaucracy literature). In Table S10 (online appendix), we replicate our analysis using this binary indicator as a measure of independence.
}

so we expect the "Fixed terms" loading to be positive. All the PCA loadings fall in line with our theoretical expectations.

Another way to assess the plausibility of our measurement model is to see how agencies rank on the independence index itself. Table A1 in the appendix shows PCA scores for all 89 agencies, including the 15 aid-giving agencies that we consider in the regression models. We see, for example, that departments rank low on independence, whereas more technical and traditionally independent agencies such as the Federal Reserve Board and the Postal Regulatory Commission rank very highly. There is also variation in the degree of independence across aid-giving agencies, with the Department of State at the low end, USAID near the mid-point of the distribution, and the Millennium Challenge Corporation near the top. This ordering conforms to our qualitative assessment of these agencies.

Finally, we note that much of the variation we see in the index would be obscured if we used the more traditional binary measure of agency independence. To see this, consider Figure 1 where we plot our independence measure against a dummy coded as 0 if the agency is an executive department or in the Executive Office of the President and 1 otherwise (Lewis and Selin 2012). ${ }^{18}$ Thus, we use our theoretically-motivated and more nuanced measure of agency independence in the regression analyses that follow.

\section{Agency Independence and Foreign Aid: A Regression Analysis}

The ideas introduced above lead us to expect that, if institutional design is effective, the relationship between diplomatic motives and aid allocation will be weaker where agencies are relatively independent from the Executive. In contrast, the positive association between development motives and ODA should be stronger in independent agencies.

We operationalize the concept of "diplomatic" aidgiving with two commonly used variables: alliance and trade. Alliance is a dummy variable that takes on a value

\footnotetext{
18 In Table S10 of the online appendix, we replicate our primary regression results using a commonly used binary measure of independence. The results support those presented here, but readers will note that the marginal effects we estimate using the binary measure are substantially smaller than the marginal effects we estimate using our continuous index of independence. This finding is consistent with the idea that the binary variable measures independence with error, thereby introducing attenuation bias in the estimation.
} 


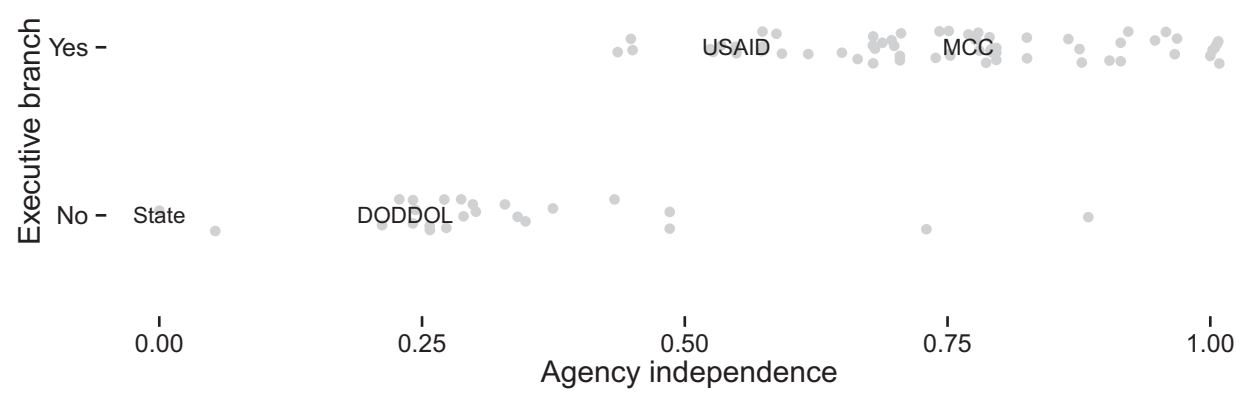

FIG 1. Continuous vs. Binary Measures of Agency Independence From the Executive. 89 US Government Agencies with Four Aid-Giving Agencies Identified by Name

of 1 if the US and the partner country have at least one of four types of alliances: defense, neutrality, nonaggression, or entente (Gibler 2013). Here, foreign aid could play the role of side-payment-that is, a reward for the past decision to conclude an alliance-or it could simply be construed as a "maintenance cost" that the US pays to remain influential in a theater that holds strategic importance. Our Alliance variable is a useful way to delineate the group of countries where the United States is likely to incur those kinds of costs.

The second measure of diplomatic motive, Trade, is the $\log$ of bilateral trade flows between the recipient and the United States (Barbieri and Keshk 2012). Relationships with major trade partners are particularly important to the president, since those countries can develop influential support coalitions within the American public and business community. To satisfy these domestic groups, the president has incentives to cultivate support abroad in order to ensure that the policies that led to fruitful economic cooperation are not overturned.

Because Alliance and Trade are imperfect proxies for diplomatic interest, the online appendix reports the results of regression models using four alternate measures: the logged number of US troops stationed in the recipient country (Kane 2006), the geographic distance from the United States (Mayer and Zignago 2006), the $\log$ of outward FDI flows from the United States to the recipient (OECD 2014a), and a dummy for the existence of a bilateral tax treaty between the United States and the recipient (Internal Revenue Service 2014). ${ }^{19,20}$

To measure "development" aid-giving, we use the log of the Infant Mortality rate as an indicator of need in recipient countries (World Bank 2013). Again, to demonstrate the robustness of our results to the choice of measure, we replicate the analysis using four alternate representations of need in the recipient country: the log of GDP per capita, share of the population living with

\footnotetext{
${ }^{19}$ All diplomacy results are consistent with our expectations, except in the distance model, where we find a negative relationship between distance and ODA flows, but no conditioning effect by the agency independence variable. See Table S13 in the online appendix.

${ }^{20}$ For prior work on the relationship between aid and alliances, see Meernik et al. 1998; Bueno de Mesquita and Smith 2007, 2009; Schraeder et al. 1998. On trade flows, see Berthelémy and Tichit 2004; Meernik et al. 1998; Bueno de Mesquita and Smith 2007, 2009; Schraeder et al. 1998. On military troops, see Meernik et al. 1998. On distance, see Dietrich 2013; Fink and Redaelli 2011; Heinrich 2013; Bueno de Mesquita and Smith 2007, 2009; Neumayer 2005; Raschky and Schwindt 2012. On FDI, see Alesina and Dollar 2000; Berthelémy and Tichit 2004.
}

HIV/AIDS, life expectancy, and proportion of the population living on less than $\$ 5$ per day. ${ }^{21}$

The dependent variable in our tests is the annual ODA commitments from US government agencies, and covers the 1999-2010 period. $^{22}$ Unless otherwise noted, our unit of observation is the agency-country-year. To estimate the moderating influence of agency independence on the relationship between policy motives and aid allocation, we use an interactive linear model of this form:

$$
\begin{aligned}
\text { ODA } & =\beta_{\text {oda }} \text { ODA }_{t-1}+\beta_{\text {ind }} \text { Independence } \\
& +\beta_{\text {mot }} \text { Motive }+\beta_{\text {indmot }} \text { Ind } . \times \text { Motive }+\beta_{\text {gdp }} \text { GDP } \\
& +\beta_{\text {pop }} \text { Population }+\beta_{\text {dem }} \text { Democracy }+\Omega+\alpha+\epsilon,
\end{aligned}
$$

where "ODA" represents the log dollar amount of ODA that a recipient country gets; "Independence" is the measure of agency independence described above; "Motive" is one of three proxy measures of foreign policy motives (military alliances, trade flows, and infant mortality); $\Omega$ is a vector of year, country, and/or agency fixed effects, or a set of agency-specific time trends; $\alpha$ is a constant; and $\varepsilon$ is the disturbance term. For obvious reasons, we also control for log GDP per capita, log population size (World Bank 2013), and the regime type of the recipient country (Marshall, Jaggers, and Gurr 2012). Where no other indication is given, models are estimated using Ordinary Least Squares, and the reported standard errors are robust to arbitrary forms of heteroskedasticity.

\section{Results}

Table 3 presents results for the models described by equation 1. The coefficient estimates are consistent with our expectations. Military alliances are positively related to ODA flows from agencies that are not shielded from influence by the Executive $\left(\beta_{\text {all }}=0.599\right.$, with $\left.p<0.01\right)$, but this relationship nearly disappears in highly independent agencies $\left(\beta_{\text {all }}+\beta_{\text {ind*all }}=0.025\right)$. Similar conclusions can be drawn from the Trade model estimates:

\footnotetext{
${ }^{21}$ See Table S12 in the online appendix. Results are consistent across all development models, except when we consider the $\$ 5$ per day variable, in which case the interaction term is of the expected sign but is not statistically significant.

22 The original data points were recorded at the project level by AidData (Tierney et al. 2011), but we aggregate them to obtain agency-level figures.
} 
TABLE 3. Relationship Between Foreign Policy Motives, Agency Independence, and ODA Allocation Patterns. Linear Models. Robust Standard Errors. The Models Include Agency and Year Fixed Effects, as well as Agency-Specific Time Trends (Omitted From the Table)

\begin{tabular}{|c|c|c|c|}
\hline & $\log (O D A) 1$ & $\log (O D A) 2$ & $\log (O D A) 3$ \\
\hline (Intercept) & $0.368(0.360)$ & $3.286(0.530)$ & $-3.669(0.543)$ \\
\hline $\log (\mathrm{ODA})_{t-1}$ & $0.672(0.008)$ & $0.676(0.008)$ & $0.676(0.007)$ \\
\hline Polity & $0.019(0.004)$ & $0.027(0.004)$ & $0.035(0.004)$ \\
\hline $\log ($ GDP/Cap) & $-0.373(0.021)$ & $-0.518(0.032)$ & $-0.150(0.032)$ \\
\hline Log (Population) & $0.142(0.018)$ & $0.000(0.028)$ & $0.197(0.017)$ \\
\hline Alliance & $0.599(0.105)$ & & \\
\hline Alliance $\times$ Independence & $-0.574(0.197)$ & & \\
\hline Log (Trade) & & $0.264(0.025)$ & \\
\hline Log $($ Trade $) \times$ Independence & & $-0.241(0.035)$ & \\
\hline Log (Infant Mortality) & & & $0.230(0.060)$ \\
\hline Log (Infant Mortality) $\times$ Independence & & & $0.248(0.087)$ \\
\hline$R^{2}$ & 0.671 & 0.665 & 0.667 \\
\hline Num. obs. & 20,037 & 20,468 & 22,666 \\
\hline
\end{tabular}

$\beta_{\text {tra }}=0.264(p<0.01)$ and $\beta_{\text {tra }}+\beta_{\text {ind } * \text { tra }}=0.023$. All aid agencies appear to respond positively to infant mortality, our indicator of recipient need $\left(\beta_{\text {inf }}=0.230\right.$, with $p<0.01)$. This tendency appears to be reinforced where agencies are independent from influence by the Executive $\left(\beta_{\text {inf }}+\beta_{\text {ind } * \text { inf }}=0.478\right)$. All three interaction term coefficients cross usual thresholds of statistical significance.

A more accessible way to convey the same basic results is to look at a graphical representation. Figure 2 plots the marginal effects of our three policy motives from Table 3. In the Alliance and Trade cases, the marginal effects of diplomacy motives on ODA in dependent agencies are positive and statistically significant at the $\alpha=0.05$ level. In the Infant Mortality case, the marginal effect slopes up as agency independence increases (moving right along the $\mathrm{x}$-axis). In concrete terms, this means that agency independence weakens the positive association between ODA flows and both military alliances and trade relationships. In contrast, agency independence reinforces the positive association between ODA flows and infant mortality.

Given the semi-log specification of the Alliance test, it is easy to get a sense of the substantive importance of the estimated effect sizes. ${ }^{23}$ On average, and holding other regressors constant, US allies tend to receive nearly $60 \%$ more ODA than nonallies where the agency lacks institutional safeguards against Executive influence. This marginal effect becomes indistinguishable from zero as soon as the degree of agency independence reaches about 0.7 on the $0-1$ scale. Similarly, a change of one standard deviation in the (logged) trade variable is associated with an increase of about $65 \%$ $(2.47 \times 0.264)$ in ODA from dependent agencies. Again, this positive relationship vanishes as we increase the degree of independence. Finally, moving from zero to one on the Independence scale is associated with an increase of about $25 \%$ in the estimated marginal effect of $\log$ (Infant Mortality).

In sum, the results described in Table 3 and Figure 2 are consistent with our theoretical expectations, and the sizes of the estimated marginal effects are large and substantively significant.

\footnotetext{
${ }^{23}$ But see Thornton and Innes (1989) for a discussion of potential problems related to the interpretation of semi-log coefficients as percentage change in the dependent variable.
}

\section{Robustness}

These results are robust to a series of alternative model specifications. We consider the two most important ones here, and list additional robustness checks in Footnote 24 , with full results recorded in the supplementary materials that accompany this article. ${ }^{24}$

The first issue we investigate relates to the panel specification of our tests, and to the fact that most of the variation in the data set is cross-sectional. Indeed, it is true that Independence is a constant for each agency and that the motive measures-Alliance, Trade, and Infant Mortalitytend to be slow moving. Still, given that there is variation over time in the policy motives variables, and considering that stickiness in the two sets of variables is "cross-cutting" (i.e., within agency vs. within country), it is reasonable to use all dimensions of the data to estimate the interaction terms that interest us. Nevertheless, our main findings do not hang on the panel structure of the data set. The first three models of Table 4 show linear model estimates obtained from a pure cross section, using only the mean of each variable at the agency-country level. Ignoring

${ }^{24}$ We re-estimated the base models from Table 3 using various combinations of country, agency, and year fixed effects (Tables S1-S3); excluded influential country and agency outliers (Tables S4 and S5); re-coded the dependent variable to take a value of 1 for any positive value of ODA and 0 otherwise and estimated a series of logistic regression models (Table S6); included all the policy motives in a single regression equation (Table S7); controlled for the occurrence of divided government (Table S8); controlled for the occurrence of inter or intrastate armed conflict (Table S9); used a more traditional dummy variable to measure independence ( 1 if an agency is outside the Executive Office of the President or an executive department and 0 otherwise (Lewis and Selin 2012)) (Table S10); re-estimated our core models with an alternative continuous measure of agency independence by Selin (forthcoming) (Table S11); considered alternative measures of need in recipient countries: the log of GDP per capita, percent of population living with less than $\$ 5$ a day, percent of population living with AIDS, and life expectancy (Table S12); considered alternative measures of US economic and military interest: $\log$ of the number of American troops stationed in the recipient country, $\log$ of net foreign direct investment outflows from the US to the recipient, and a binary indicator for the existence of a bilateral tax treaty between the US and the recipient (Table S13); and accounted for uncertainty in the estimation of our measure of agency independence by applying a nonparametric bootstrap to the PCA model and using the method of composition (Tanner 1991) to "propagate" the estimated uncertainty into our main regression models (Table S14). We were also hoping to treat seriously the potential endogeneity between foreign aid and trade flows, but were unable to find an instrumental variable which meets the exclusion restriction requirement. For lack of better options, we lagged all the regressors by a year and re-estimated all our main models (Table S15). Again, the main results remain substantively unchanged. 


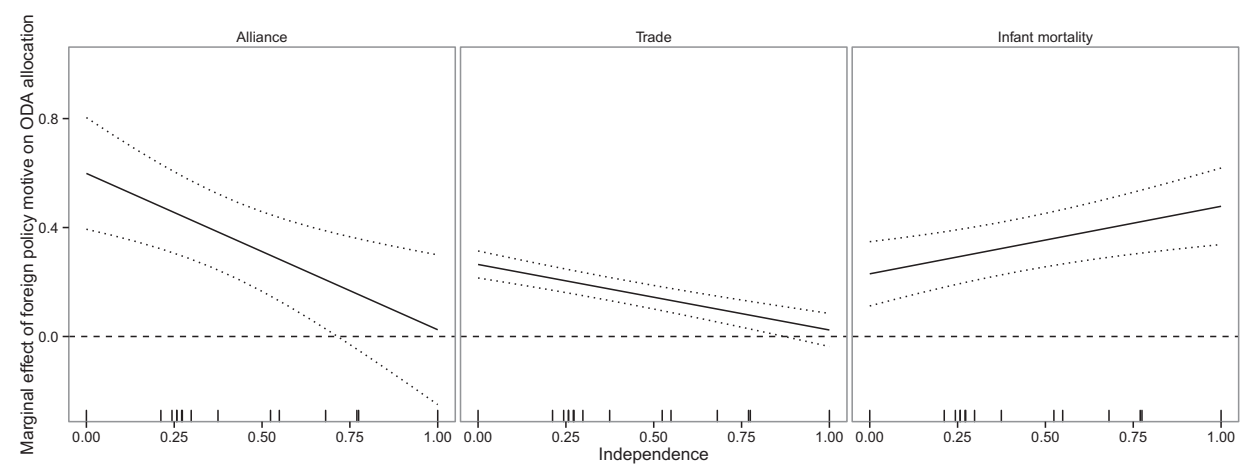

FIG 2. Marginal Effects of Policy Motives on ODA Allocation.

(Note. Dotted lines represent 95\% confidence bands. Rug plots indicate the location of each aid-giving agency on the independence scale.)

TABle 4. Cross-Sectional Relationship Between Foreign Policy Motives, Agency Independence, and ODA Allocation Patterns. Ordinary Least Squares and Robust M-Estimator Regressions

\begin{tabular}{|c|c|c|c|c|c|c|}
\hline & OLS 1 & OLS 2 & OLS 3 & M 1 & $M 2$ & M 3 \\
\hline (Intercept) & $-4.257(1.192)$ & $-6.630(1.223)$ & $-6.109(1.271)$ & $-0.084(0.269)$ & $-0.553(0.292)$ & $-0.329(0.303)$ \\
\hline Polity & $0.064(0.019)$ & $0.095(0.017)$ & $0.116(0.017)$ & $0.008(0.004)$ & $0.011(0.004)$ & $0.015(0.004)$ \\
\hline Log (Population) & $0.470(0.074)$ & $0.617(0.080)$ & $0.425(0.074)$ & $0.036(0.017)$ & $0.045(0.019)$ & $0.027(0.017)$ \\
\hline Independence & $0.206(0.423)$ & $3.794(1.147)$ & $-2.867(1.238)$ & $-0.381(0.096)$ & $0.587(0.254)$ & $-0.539(0.316)$ \\
\hline Alliance & $1.081(0.453)$ & & & $0.330(0.106)$ & & \\
\hline Alliance $\times$ Independence & $-1.669(0.970)$ & & & $-0.575(0.198)$ & & \\
\hline Log (Trade) & & $0.031(0.075)$ & & & $0.057(0.019)$ & \\
\hline Log $($ Trade $) \times$ Independence & & $-0.601(0.162)$ & & & $-0.159(0.036)$ & \\
\hline Log (Infant Mortality) & & & $0.789(0.171)$ & & & $0.130(0.046)$ \\
\hline Log (Infant & & & $0.778(0.371)$ & & & $0.021(0.092)$ \\
\hline Mortality) $\times$ Independence & & & & & & \\
\hline$R^{2}$ & 0.034 & 0.043 & 0.062 & 0.006 & 0.007 & 0.008 \\
\hline Num. obs. & 1828 & 1828 & 1828 & 1828 & 1828 & 1828 \\
\hline
\end{tabular}

the time dimension does not affect our results in a meaningful way. For example, an increase of one in Alliance is associated with an increase of 1.081 in $\log (O D A)$ when Independence equals zero, but with a reduction of 0.588 when Independence equals one (the latter is statistically indistinguishable from zero). Likewise, the interaction term in the Trade OLS specification is negative, while the Infant Mortality interaction is positive and statistically significant.

A second potential concern is that outliers may drive our results. Certain high leverage countries, for example, Afghanistan and Egypt, receive large amounts of foreign aid and are strategically important for the US president. Similarly, a few of the aid-giving agencies may hold disproportionate weight in our analysis, either because they account for a large share of total ODA (for example, USAID), or because they combine a high degree of independence with a narrow regional focus (for example, the African Development Foundation).

A natural way to guard against this potential outlier problem is to re-estimate models while excluding problematic observations. In the online appendix (Tables S4 and S5), we show that the exclusion of extreme countries and agencies does not affect our substantive conclusions. A less ad hoc approach is to use a high breakdown point M-estimator. The three right-most columns of Table 4 show the results we obtained using the lmRob procedure (Wang, Zamar, Marazzi, Yohai, Salibian-Barrera, Maronna,
Zivot, Rocke, Martin, Maechler, and Konis 2013) to re-estimate our cross-sectional models. Again, the results are broadly consistent with our expectations.

\section{Conclusion}

We find that the institutional setup of the US bureaucracy matters a great deal for the distribution of foreign aid. Our argument highlights the role of domestic institutions, and thus challenges the assumption that the Executive can target aid wherever she sees fit. We point out that a host of government agencies actually disburse aid. These agencies can hamstring the Executive, making her foreign policy goals difficult to achieve. We study the success of the Executive in overcoming this managerial problem in the context of one case: American foreign aid-giving. Using a newly created continuous measure of independence for US aid agencies, we show that when agencies are dependent on the Executive, ODA flows closely connect to the diplomatic goals of the president. Where agencies enjoy independence, or insulation from Executive pressure, ODA flows better match development ends than the administration's foreign policy motives. In sum, agency independence effectively inhibits the president from directing foreign aid toward diplomatic priorities.

These results suggest that the pool of resources available for Executive diplomacy may differ in systematic 
TABLE 5. Number of Aid-Giving Agencies and ODA Commitments in the 15 Largest Donor Nations (2012)

\begin{tabular}{lcc}
\hline Donor & ODA (Billion USD) & Agency count \\
\hline United States & 30.69 & 15 \\
United Kingdom & 13.89 & 6 \\
Germany & 12.94 & 17 \\
France & 12.03 & 17 \\
Japan & 10.60 & 12 \\
Canada & 5.65 & 10 \\
Netherlands & 5.52 & 5 \\
Australia & 5.40 & 2 \\
Sweden & 5.24 & 6 \\
Norway & 4.75 & 7 \\
Switzerland & 3.05 & 9 \\
Italy & 2.74 & 9 \\
Denmark & 2.69 & 3 \\
Belgium & 2.31 & 10 \\
Spain & 2.04 & 18 \\
\hline
\end{tabular}

(Note. Sources: OECD (2014a,b); Tierney et al. (2011).)

fashion from the aggregate ODA figures that scholars generally focus on. In particular, inferences drawn from aggregate data could both overestimate the responsiveness of independent agencies to diplomatic motives, and underestimate their responsiveness to development need. Our findings suggest a more nuanced interpretation of domestic political institutions on the donor side. They complement an emerging strand of research on the types and channels of aid-giving (Fariss 2010; Winters 2010; Raschky and Schwindt 2012; Dietrich 2013).

The lessons of our study can also inform the understanding of aid politics outside the United States. All major donor countries use multiple government agencies to distribute foreign aid (see Table 5). This suggests an immediate path forward for future research: extending our analysis cross-nationally. This would address whether the independence of government aid-giving agencies varies systematically across countries, providing new ground for empirical tests of our expectations. In addition, a cross-national study should explore how other features of the political system, such as the rule of law or the number of veto players, affect an agency's de facto degree of independence.

Our research also contributes to our understanding of bureaucratic politics by addressing the extent to which agency independence acts as a firewall against presidential influence. While we do not provide a general answer to the question of whether de jure agency independence translates into de facto independence, our evidence shows an attenuation of executive influence in one particular domain: foreign aid.

This study highlights the importance of agency-level characteristics in influencing foreign aid distribution. Future work should consider the design of the bureaucracy and employ disaggregated data to explore how other agency features shape foreign policy outcomes. For instance, while we focus here on agency independence, bureaucratic expertise can also foster agency autonomy (Gailmard and Patty 2013) and may enable agencies to take positions that diverge from the Executive. Given the range and variety of agencies involved in implementing foreign policy, research that explores the role of bureaucratic administration constitutes an agenda in its own right.

While this paper focuses on aid-giving in the US context, our findings can also shed light on a much broader set of topics in the study of foreign policy. For example, the Federal Reserve and the Department of Treasurytwo agencies characterized by very different levels of structural independence from the Executive-both hold policy levers that can have tremendous effects on the US position in the international capital markets. Immigration policy represents another complex case for the Executive, as its implementation relies on numerous agencies at the federal level-including the Department of Homeland Security, the Department of Justice, the Department of Labor, and the Department of State-as well as the federal judiciary and a dizzying assortment of state and local law enforcement agencies. Considering the bureaucratic design of the many agencies involved in these foreign policy areas may help explain why different actors perceive - and respond to - a single country's foreign policy position in different ways.

\section{Appendix}

TABLE A1. (continued)

TABLE A1. Agency Independence Estimates for 89 U.S. Government Agencies. Aid-giving Agencies in Bold

\begin{tabular}{lc}
\hline Agency & Independence \\
\hline Appalachian Regional Commission & 0.55 \\
Barry Goldwater Scholarship and Excellence & 0.71 \\
$\quad$ in Education Program & \\
Board of Veterans' Appeals & 0.88 \\
Broadcasting Board of Governors & 0.75 \\
Central Intelligence Agency & 0.57 \\
Chemical Safety and Hazard Investigation Board & 1.01 \\
Commodity Futures Trading Commission & 0.66 \\
Consumer Product Safety Commission & 0.92 \\
Corporation for National and Community Service & 0.78 \\
Council of Economic Advisers & 0.49 \\
Council on Environmental Quality & 0.49 \\
Defense Nuclear Facilities Safety Board & 0.79 \\
Department of Agriculture & 0.24 \\
Department of Commerce & 0.23 \\
Department of Defense & 0.21 \\
Department of Education & 0.24 \\
\hline
\end{tabular}

\begin{tabular}{lc}
\hline Agency & Independence \\
\hline Department of Energy & 0.27 \\
Department of Health and Human Services & 0.26 \\
Department of Homeland Security & 0.24 \\
Department of Housing and Urban Development & 0.29 \\
Department of the Interior & 0.30 \\
Department of Justice & 0.05 \\
Department of Labor & 0.26 \\
Department of State & 0 \\
Department of Transportation & 0.29 \\
Department of the Treasury & 0.27 \\
Department of Veterans Affairs & 0.35 \\
Environmental Protection Agency & 0.44 \\
Equal Employment Opportunity Commission & 0.70 \\
Export-Import Bank of the United States & 0.68 \\
Farm Credit Administration & 0.74 \\
Federal Communications Commission & 0.65 \\
Federal Deposit Insurance Corporation & 0.75 \\
Federal Election Commission & 0.79 \\
Federal Energy Regulatory Commission & 0.73 \\
Federal Housing Finance Agency & 0.83 \\
\hline
\end{tabular}


TABLE A1. (continued)

\begin{tabular}{lc}
\hline Agency & Independence \\
\hline Federal Labor Relations Authority & 0.83 \\
Federal Maritime Commission & 0.88 \\
Federal Mediation and Conciliation Service & 0.57 \\
Federal Mine Safety and Health Review Commission & 0.97 \\
Federal Reserve Board & 1 \\
Federal Retirement Thrift Investment Board & 0.79 \\
Federal Trade Commission & 0.86 \\
General Services Administration & 0.45 \\
Harry S. Truman Scholarship Foundation & 0.80 \\
Institute for Museum and Library Services & 0.78 \\
Inter-American Foundation & 0.80 \\
James Madison Memorial Fellowship Foundation & 0.80 \\
Merit Systems Protection Board & 0.97 \\
Millennium Challenge Corporation & 0.77 \\
National Aeronautics and Space Administration & 0.45 \\
National Council on Disability & 0.78 \\
National Credit Union Administration & 0.59 \\
National Endowment for the Arts & 0.68 \\
National Endowment for the Humanities & 0.62 \\
National Labor Relations Board & 0.91 \\
National Mediation Board & 0.88 \\
National Science Foundation & 0.78 \\
National Security Education Board & 0.75 \\
National Security Staff & 0.43 \\
National Transportation Safety Board & 0.95 \\
Nuclear Regulatory Commission & 0.91 \\
Occupational Safety and Health Review Commission & 0.96 \\
\hline & \\
\hline & \\
\hline
\end{tabular}

\section{References}

Alesina, Alberto, And David Dollar. (2000) Who Gives Foreign Aid to Whom and Why? Journal of Economic Growth 5 (1): 33-63.

Alesina, Alberto, and Lawrence H. Summers. (1993) Central Bank Independence and Macroeconomic Performance: Some Comparative Evidence. Journal of Money, Credit, and Banking 25 (2): 151-163.

Barbieri, Katherine, and Omar Keshk. (2012) Correlates of War Project Trade Data Set Codebook, Version 3.0. Available at http:// correlatesofwar.org (Accessed January 9, 2015).

Barkow, Rachel. (2010) Insulating Agencies: Avoiding Capture Through Institutional Design. Texas Law Review 89: 15-79.

Barro, Robert J., And David B. Gordon. (1983) Rules, Discretion, and Reputation in a Model of Monetary Policy. Journal of Monetary Economics 12 (1): 101-121.

Bearce, David H., And Daniel C. Tirone. (2010) Foreign Aid Effectiveness and the Strategic Goals of Donor Governments. The Journal of Politics 72 (3): 837-851.

Berthelémy, Jean-Claude. (2006) Bilateral Donors' Interest vs. Recipients' Development Motives in Aid Allocation: Do All Donors Behave the Same? Review of Development Economics 10 (2): 179-194.

Berthelémy, Jean-Claude, and Ariance Tichit. (2004) Bilateral Donors' Aid Allocation Decisions - A Three-Dimensional Panel Analysis. International Review of Economics and Finance 13 (3): 253-274.

Boone, Peter. (1996) Politics and the Effectiveness of Foreign Aid. European Economic Review 40 (2): 289-329.

Brehm, John, And Scott Gates. (1993) Donut Shops and Speed Traps: Evaluating Models of Supervision on Police Behavior. American Journal of Political Science 37 (2): 555-581.

Bressman, Lisa Schultz, And Robert B. Thompson. (2010) The Future of Agency Independence. Vanderbilt Law Review 63 (3): 599672.

Bueno de Mesquita, Bruce, and Alastair Smith. (2007) Foreign Aid and Policy Concessions. Journal of Conflict Resolution 51 (2):251-284.

Bueno de Mesquita, Bruce, and Alastair Smith. (2009) A Political Economy of Aid. International Organization 63 (2):309-340.

Burnside, Craig, and David Dollar. (2000) Aid, Policies, and Growth. American Economic Review 90 (4): 847-868.
TABLE A1. (continued)

\begin{tabular}{|c|c|}
\hline Agency & Independence \\
\hline Office of Government Ethics & 0.68 \\
\hline Office of Management and Budget & 0.34 \\
\hline Office of National Drug Control Policy & 0.30 \\
\hline Office of Navajo and Hopi Indian Relocation & 0.70 \\
\hline Office of Personnel Management & 0.59 \\
\hline Office of Science and Technology & 0.37 \\
\hline Office of Special Counsel & 0.90 \\
\hline $\begin{array}{l}\text { Office of the Federal Coordinator for Alaska Natural } \\
\text { Gas Transportation Projects }\end{array}$ & 0.70 \\
\hline Office of the United States Trade Representative & 0.33 \\
\hline Overseas Private Investment Corporation & 0.69 \\
\hline Peace Corps & 0.57 \\
\hline Postal Regulatory Commission & 1.01 \\
\hline Railroad Retirement Board & 0.79 \\
\hline Securities and Exchange Commission & 0.70 \\
\hline Selective Service System & 0.53 \\
\hline Small Business Administration & 0.53 \\
\hline Social Security Administration & 0.74 \\
\hline Surface Transportation Board & 1.01 \\
\hline Tennessee Valley Authority & 0.79 \\
\hline United States African Development Foundation & 0.77 \\
\hline United States Agency for International Development & 0.55 \\
\hline United States Election Assistance Commission & 0.79 \\
\hline United States Institute of Peace & 1 \\
\hline United States International Trade Commission & 0.68 \\
\hline United States Postal Service & 1 \\
\hline United States Trade and Development Agency & 0.52 \\
\hline
\end{tabular}

Canes-Wrone, Brandice. (2005) Who Leads Whom? Presidents, Policy and the Public. Chicago: University of Chicago Press.

Canes-Wrone, Brandice, William G. Howell, and David E. Lewis. (2008) Toward a Broader Understanding of Presidential Power: A Reevaluation of the Two Presidencies Thesis. The Journal of Politics 70 (1): 1-16.

Carpenter, Daniel P. (2001) The Forging of Bureaucratic Autonomy: Reputations, Networks, and Policy Innovation in Executive Agencies, 1862-1928. Princeton: Princeton University Press.

Carpenter, Daniel P. (2010) Reputation and Power: Organizational Image and Pharmaceutical Regulation at the FDA. Princeton: Princeton University Press.

Cukierman, Alex. (1992) Central Bank Strategy, Credibility, and Independence: Theory and Evidence. Cambridge: MIT Press.

De Long, Bradford, and Lawrence H. Summers. (1992) Macroeconomic Policy and Long-Run Growth. Economic ReviewFederal Reserve Bank of Kansas City 77 (4):5-30.

Delli Carpini, Michael X., And Scott Keeter. (1993) Measuring Political Knowledge: Putting First Things First. American Journal of Political Science 37 (4): 1179-1206.

Department of State. (2014) Highlights of the Department of State and US Agency for International Development Budget. Fact Sheet Available at http://www.state.gov/r/pa/prs/ps/2014/03/222870. htm (Accessed January 9, 2015).

Derthick, Martha, and Paul J. Quirk. (1985) The Politics of Deregulation. Washington, DC: Brookings Institution Press.

Devins, Neal, and David E. Lewis. (2008) Not-So Independent Agencies: Party Polarization and the Limits of Institutional Design. Boston University Law Review 88: 459.

Dietrich, Simone. (2013) Bypass or Engage? Explaining Donor Delivery Tactics in Foreign Aid Allocation. International Studies Quarterly 57 (4): 698-712.

Dilulio, John D. (1994) Principled Agents: The Cultural Bases of Behavior in a Federal Government Bureaucracy. Journal of Public Administration Research and Theory 4 (3): 277-318.

Fariss, Christopher J. (2010) The Strategic Substitution of United States Foreign Aid. Foreign Policy Analysis 6 (2): 107-131. 
Fink, Guenther, and Silvia Redaelli. (2011) Determinants of International Emergency Aid: Humanitarian Need Only? World Development 39 (5): 741-757.

Franzese, Robert J. (1999) Partially Independent Central Banks, Politically Responsive Governments, and Inflation. American Journal of Political Science 43 (3): 681-706.

Gailmard, Sean, and John W. Patty. (2007) Slackers and Zealots: Civil Service, Policy Discretion, and Bureaucratic Expertise. American Journal of Political Science 51 (4): 873-889.

Gailmard, Sean, and John W. Patty. (2013) Learning While Governing: Expertise and Accountability, in the Executive Branch. Chicago: University of Chicago Press.

Gibler, Douglas M. (2013) International Military Alliances 1648-2009 (v4.1) Available at http://www.correlatesofwar.org/ (Accessed January 9, 2015).

Golden, Marissa Martino. (2000) What Motivates Bureaucrats?: Politics and Administration During the Reagan Years. New York: Columbia University Press.

Hammond, Thomas H., and Jack H. Knotт. (1996) Who Controls the Bureaucracy?: Presidential Power, Congressional Dominance, Legal Constraints, and Bureaucratic Autonomy in a Model of MultiInstitutional Policymaking. Journal of Law, Economics, and Organization 12 (1): 119-166.

Heinrich, Tobias. (2013) When is Foreign Aid Selfish, When is it Selfless? The Journal of Politics 75 (2): 422-435.

Hibbs, Douglas A. Jr (2000) Bread and Peace Voting in U.S. Presidential Elections. Public Choice 104 (1-2):149-180.

Holsti, Kalevi JaAko. (2004) Taming the Sovereigns: Institutional Change in International Politics, Vol. 94. New York: Cambridge University Press.

Internal Revenue Service. (2014) United States Income Tax Treaties. Available at http://www.irs.gov/Businesses/InternationalBusinesses/United-States-Income-Tax-Treaties-A-to-Z (Accessed January 9,2015 )

International Aid Transparency Initiative. (2014) About IATI. Available at http://www.aidtransparency.net/about (Accessed August 4, 2014).

Kane, Tim J. (2006) Global U.S. Troop Deployment, 1950-2005. Hudson Institute. Available at http://ssrn.com/abstract=1146649 (Accessed January 9,2015$)$.

Kaufman, Herbert. (1960) The Forest Ranger: A Study in Administrative Behavior. Washington, DC: Resources for the Future.

Krasner, Stephen D. (1978) Defending the National Interest: Raw Materials Investments and US Foreign Policy. Princeton: Princeton University Press.

Kuziemko, Ilyana, and Eric Werker. (2006) How Much is a Seat on the Security Council Worth? Foreign Aid and Bribery at the United Nations. Journal of Political Economy 114 (5): 905-930.

Lancaster, Carol. (2007) Foreign Aid: Diplomacy, Development, Domestic Politics. Chicago: University of Chicago Press.

Lawson, Marian Leonardo. (2013) Does Foreign Aid Work? Efforts to Evaluate U.S. Foreign Assistance. Technical report. Washington, DC: Congressional Research Service.

Leahy, Patrick. (2011) Cuts to Foreign Aid Cost the U.S. Globally. U.S. News \& World Report, Oct. 11.

Lebovic, James, and Eric Voeten. (2009) The Cost of Shame: International Organizations and Foreign Aid in the Punishing of Human Rights Violators. Journal of Peace Research 46 (1): 79-97.

Lewis, David E. (2003) Presidents and the Politics of Agency Design. Palo Alto: Stanford University Press.

Lewis, David E., And Jennifer L. Selin. (2012) Sourcebook of United States Executive Agencies. Technical report. Washington, DC: Administrative Conference of the United States.

Lewis-Beck, Michael S., and Mary Stegmaier. (2000) Economic Determinants of Electoral Outcomes. Annual Review of Political Science 3 (1): 183-219.

Lohmann, Susanne. (1992) Optimal Commitment in Monetary Policy: Credibility Versus Flexibility. American Economic Review 82 (1): 273286.

Maizels, Alfred, and Machiko K. Nissanke. (1984) Motivations for Aid to Developing Countries. World Development 12 (9): 879-900.

Mansfield, Edward D., Helen V. Milner, and B. Peter Rosendorff. (2002) Why Democracies Cooperate More: Electoral Control and International Trade Agreements. International Organization 56 (3): $477-513$.
Marshall, Mony G., Keith Jaggers, and Ted Robert Gurr. (2012) Polity IV Project. Available at http://www.systemicpeace.org/polity/ polity4.htm (Accessed January 9, 2015).

Mayer, T., And Zignago, S. (2006) GeoDist: The CEPII Distances and Geographical Database. Available at http://www.cepii.fr/ cepii/en/bdd_modele/presentation.asp?id=6 (Accessed January 9, 2015).

McKinlay, Robert D., and Richard Little. (1977) A Foreign Policy Model of US Bilateral Aid Allocation. World Politics 30 (1): 58-86.

Meernik, James, Eric L. Krueger, and Steven C. Poe. (1998) Testing Models of U.S. Foreign Policy: Foreign Aid During and After the Cold War. Journal of Politics 60: 63-85.

Milner, Helen V., and Dustin H. Tingley. (2010) The Political Economy of US Foreign Aid: American Legislators and the Domestic Politics of Aid. Economics E Politics 22: 200-232.

Moe, Terry M., and William G. Howell. (1999) The Presidential Power of Unilateral Action. Journal of Law, Economics, and Organization 15 (1): 132-179.

Neumayer, Eric. (2005) Is the Allocation of Food Aid Free From Donor Interest Bias? Journal of Development Studies 41 (3): 394-411.

Neustadt, Richard E. (1962) Presidential Power: The Politics of Leadership. New York: Wiley.

Niskanen, William. (1971) Bureaucracy and Representative Government. Chicago: Aldine.

Noel, Alain, and Jean-Philippe Therien. (1995) From Domestic to International Justice: The Welfare State and Foreign Aid. International Organization 49 (3): 523-553.

Nowels, Larry. (2003) Millennium Challenge Account: Congressional Consideration of a New Foreign Aid Initiative. Technical report, Congressional Research Service. Available at http://fpc.state.gov/documents/organization/39340.pdf (Accessed January 9,2015$)$.

OECD. (2014a) Aid Statistics - Organization for Economic Cooperation and Development. Available at http://www.oecd.org/dac/stats/aidat-a-glance.htm (Accessed January 9, 2015).

OECD. (2014b) OECD Statistics - Organization for Economic Cooperation and Development. Available at http://stats.oecd.org/ (Accessed January 9, 2015).

Ostrom, Charles W. Jr, and Denis M. Simon. (1985) Promise and Performance: A Dynamic Model of Presidential Popularity. American Political Science Review 79 (2): 334-358.

Page, Benjamin I., and Robert Y. Shapiro. (1983) Effects of Public Opinion on Policy. American Political Science Review 77 (1): 175-190.

Powlick, Philip J., and Andrew Z. Katz. (1998) Defining the American Public Opinion/Foreign Policy Nexus. Mershon International Studies Review 42 (1): 29-61.

Provost, Claire. (2011) Aid From OECD Countries-Who Gives the Most and how has it Changed? The Guardian, April 6. Available at http://www.theguardian.com/news/datablog/2011/apr/06/aidoecd-given (Accessed January 9, 2015).

Raschky, Paul A., and Manijeh Schwindt. (2012) On the Channel and Type of Aid: The Case of International Disaster Assistance. European Journal of Political Economy 28 (1): 119-131.

Rogoff, Kenneth. (1985) The Optimal Degree of Commitment to an Intermediate Monetary Target. Quarterly Journal of Economics 100 (4): 1169-1189.

Schraeder, Peter J., Steven W. Hook, and Bruce Taylor. (1998) Clarifying the Foreign Aid Puzzle: A Comparison of American, Japanese, French, and Swedish Aid Flows. World Politics 50 (2): 294-323.

Selin, Jennifer L. (Forthcoming) What Makes an Agency Independent? American Journal of Political Science.

Sorrells, Niels C. (2003) 'New' Aid Plan Looks Familiar. CQ Weekly, May 24.

Svensson, Јаков. (1999) Aid, Growth and Democracy. Economics $\mathcal{E}^{\circ}$ Politics 11 (3):275-297.

Tanner, Martin A. (1991) Tools for Statistical Inference, Vol. 3. New York: Springer.

Therien, Jean-Philippe, and Alain Noel. (2000) Political Parties and Foreign Aid. American Political Science Review 94 (1): 151-162.

Thornton, Robert J., AND Jon T. Innes. (1989) Interpreting Semilogarithmic Regression Coefficients in Labor Research. Journal of Labor Research 10 (4): 443-447.

Tierney, Michael J., Daniel L. Nielson, Darren G. Hawkins, J. Timmons Roberts, Michael G. Findley, Ryan M. Powers, 
Bradley Parks, Sven E. Wilson, And Robert L. Hicks. (2011) More Dollars Than Sense: Refining Our Knowledge of Development Finance Using AidData. World Development 39 (11): 1891-1906.

Tulis, Jeffery. (1987) The Rhetorical Presidency. Princeton: Princeton University Press.

Wang, Jiahui, Ruben Zamar, Alfio Marazzi, Victor Yohai, Matias Salibian-Barrera, Ricardo Maronna, Eric Zivot, David Rocke, Doug Martin, Martin Maechler, and KJell Konis. (2013) Robust: Robust Library. The Comprehensive R Archive Network: R package version 0.4-15.

Wildavsky, AaAron. (1966) The Two Presidencies. Trans-Action 4 (December): 7-14.

Wilson, James Q. (1989) Bureaucracy: What Government Agencies do and Why They do it. New York: Basic Books.

Winters, Matthew. (2010) Choosing to Target: What Types of Countries get Different Types of World Bank Projects. World Politics 62 (3): 422-458.

Wood, B. Dan, And John Bohte. (2004) Political Transaction Costs and the Politics of Administrative Design. Journal of Politics 66 (1): 176202.

World BANk. (2013) World Development Indicators. Available at http://data.worldbank.org/data-catalog/world-developmentindicators (Accessed January 9, 2015).

\section{Supporting Information}

Additional Supporting Information may be found in the online version of this article:

Table S1. Models from Table 3 with recipient and agency fixed effects.

Table S2. Models from Table 3 with agency and year fixed effects.

Table S3. Models from Table 3 with recipient and year fixed effects.

Table S4. Models from Table 3, but excluding agency outliers.

Table S5. Models from Table 3, but excluding country outliers - Afghanistan, Colombia, Egypt, Iraq, Israel, Israel, Pakistan.

Table S6. Probability of obtaining U.S. ODA, and value of ODA receipts in the recipient subsample. Logit and ordinary least squares models. Agency-specific time trends omitted from the table.

Table S7. Models from Table 3, but controlling for all foreign policy motives in each equation.

Table S8. Models from Table 3 with additional control variable for divided government in the U.S.

Table S9. Models from Table 3 with additional control for the occurence of intersate/intrastate intermediate armed conflicts or wars (UCDP).

Table S10. Models from Table 3, but using a binary Independence measure.

Table S11. Models from Table 3, but using an alternative measure of agency Independence from Selin (Forthcoming).

Table S12. Alternative measures of development need income per capita, \% of AIDS in the Log (Population), \% of Log (Population) under $5 \$$ per day, and life expectancy.

Table S13. Models from Table 3 with alternative measures of U.S. diplomatic interest - Troops stationed in the recipient country, Distance from the U.S., net FDI outflow from the U.S. to the recipient, and bilateral tax treaty.

Table S14. Bootstrapped PCA model with method of composition.

Table S15. Models from Table 3, but with all regressors lagged by one year.

Figure S1. Distribution of ODA receipts by country and agency (1 of 2).

Figure S2. Distribution of ODA receipts by country and agency (2 of 2 ). 